\title{
PEMBELAJARAN DARING ULUMUL HADITS: RESPON MAHASISWA DAN DAMPAKNYA TERHADAP NILAI AKHIR SEMESTER
}

\author{
Nur Laily Fauziyah \\ Sekolah Tinggi Ilmu Tarbiyah Al Marhalah Al 'Ulya Bekasi \\ lailyfauziyah@gmail.com
}

\begin{abstract}
This study aims to identify the students' response in Ulumul Hadis online learning and its effect toward their achievement. The method used was descriptive qualitative. The research subjects were students at semester four of Islamic Education Department in STIT Al Marhalah Al 'Ulya. The data was obtained from google form questionnaires sent to students who joined Ulumul Hadis class and from interviewing to some students. Data analysis technique used are reduction, data display, and verification. The result is that students' response during having Ulumul Hadis online learning using Whatsapp media is categorized by "agree", meanwhile from interview shows "positive" responses and they declare agreement. The use of Whatsapp in Ulumul Hadis online learning gain the significant or positive effect toward students' achievement proved by the students average score i.e. 80 to 90 (A), both morning and evening class. Have a positive impact because student feel that the benefits of WhatsApp media make it easy for them, especially in uploading paper assignments and are not too burdensome in terms of internet quota packages.
\end{abstract}

Keywords : online, learning, whatsapp, ulumul hadis, impact, final score

\begin{abstract}
ABSTRAK
Tujuan penelitian ini yaitu untuk mengetahui respon mahasiswa dalam pembelajaran daring mata kuliah Ulumul Hadits dan dampaknya terhadap hasil belajar. metode yang digunakan dalam penelitian ini adalah deskriptif kualitatif. Subjek dalam penelitian ini adalah mahasiswa semester 4 prodi Pendidikan Agama Islam Sekolah Tinggi Ilmu Tarbiyah Al Marhalah Al 'Ulya. Data diperoleh dari pengisian angket melalui google form dikirim pada mahasiswa yang mengikuti perkuliahan Ulumul Hadits dan hasil wawancara sebagian mahasiswa. Teknik analisis data yang digunakan adalah reduksi data, penyajian data dan penarikan kesimpulan. Hasil analisis dari angket bahwa rata-rata respon mahasiswa selama pembelajaran daring mata kuliah Ulumul Hadits dengan menggunakan media Whatsapp berada pada kategori setuju, dan juga hasil wawancara sebagian mahasiswa memberikan respon positif serta menyatakan setuju. Sedangkan penggunaan media whatsap dalam pembelajaran daring ulumul hadits memberikan dampak yang signifikan atau positif terhadap nilai akhir mahasiswa dibuktikan dengan rata-rata mahasiswa mendapatkan nilai 80 hingga 90 atau nilai bentuk huruf yakni A, baik pada kelas pagi maupun kelas sore. Berdampak positif karena mahasiswa merasakan bahwa manfaat media whatsapp memberikan kemudahan pada mereka baik dalam mengunggah-mengeshare tugas makalah dan tidak terlalu membebani dalam hal paket kuota internet
\end{abstract}

Kata Kunci : pembelajaran, daring, whatsapp, ulumul hadits, dampak, nilai akhir 


\section{PENDAHULUAN}

Wabah covid-19 saat ini sudah menyebar ke seluruh penjuru dunia, termasuk Indonesia yang sudah mengakibatkan banyak orang meninggal dunia. Semenjak covid-19 semua aspek kehidupan terutama pendidikan mengalami keterpurukan. Baik dari jenjang pendidikan rendah hingga jenjang pendidikan sangat tinggi.

Pembelajaran yang awalnya klasikal secara offline, berubah menjadi pembelajaran daring (online). Pembelajaran daring menjadi masalah bagi mahasiswa terutama mahasiswa yang ekonominya kurang atau pas-pasan, tidak mempunyai Laptop, Hp atau harus bergantian dengan saudara serta orangtuanya, dan mahasiswa yang tinggal di daerah pelosok yang mana jaringan internetnya terkadang macet, sehingga tidak bisa maksimal dalam mengikuti pembeajaran jarak jauh.

STIT Al Marhalah Al 'Ulya Bekasi menetapkan pencegahan penyebaran covid-19 diberlakukan sejak Maret 2020 berdasarkan himbauan dari pimpinan STIT. Menyatakan bahwa semua perkuliahan baik secara teori, tugas terstruktur dan tugas mandiri dilaksanakan dengan menggunakan aplikasi email, whatsapp group, zoom, google meet atau sejenisnya. Pembimbingan tugas akhir atau skripsi dilakukan secara online, kegiatan praktik lapangan (PPL) dilakukan secara offline dan online, namun waktunya dipersingkat atau dipadatkan.

Dalam prodi Pendidikan Agama Islam STIT AL Marhalah Al 'Ulya, sebagian besar perkuliahan menggunakan aplikasi zoom dan google meet, karena banyak dosen yang menggunakan atau memanfaatkan aplikasi tersebut dalam proses pembelajaran/perkuliahan, maka dalam mata kuliah ulumul hadits khususnya, mahasiswa menyarankan dosen pengampu agar menggunakan media whatsapp salah satunya untuk menghemat paket internet.

Menurut Suryadi (2018) yang dikutip Nur'aini dalam jurnalnya, bahwa WhatsApp Messenger itu sendiri merupakan aplikasi pesan lintas platform yang memungkinkan seseorang bertukar informasi tanpa biaya SMS. Aplikasi WhatsApp dapat digunakan untuk bertukar informasi berupa gambar maupun pesan, sehingga sangat memungkinkan jika harus melakukan pembelajaran melalui diskusi dan pengiriman materi. (Nur'aini

Namun, disisi lain dalam penggunaan teknologi juga tetap ada masalah diantaranya menurut Syah (2020) bahwa adanya keterbatasan penguasaan teknologi informasi oleh guru dan siswa, masih kurangnya sarana dan prasarana, guru dan siswa memiliki akses internet yang terbatas serta kurangnya siap penyediaan anggaran. Berdasarkan pendapat Syah Aji tersebut dapat dibenarkan karena masih banyak daerah-daerah pelosok indonesia yang belum mampu dijangkau oleh jaringan internet. Walaupun pihak kementerian telah menyediakan paket internet untuk guru dan siswa.

Kegiatan pembelajaran atau perkuliahan terkendala pada alat dan media pembelajaran yang digunakan atau yang diakses oleh mahasiswa. Permasalahan muncul dari beberapa hal, baik dari bahan ajar, pendidik, sarana prasarana seperti media belajar serta dari mahasiswa itu sendiri. Permasalahan dari pendidik atau dosen bisa dari strategi, cara atau metode pembelajaran yang digunakan yang terkadang monoton sehingga menjadikan peserta didik atau mahasiswa kurang semangat. Permasalahan dari bahan ajar dan media yaitu kurang sesuainya antara materi dengan media yang digunakan. Permasalahan dari peserta didik datang dari 
motivasi diri dalam belajar, kurang tertariknya materi pelajaran/perkuliahan atau dengan media yang digunakan, juga dari kondisi kesehatan fisik maupun mental.

Oleh karena itu dalam proses pelaksanaan pembelajaran perlu dilakukan evaluasi, dan hasil evaluasi dapat digunakan untuk memperbaiki proses pembelajaran. Baik tidaknya suatu proses pembelajaran dapat dilihat dari respon peserta didik. Respon tersebut bisa menunjukkan kepuasan dan ketercapaian dari tujuan pembelajaran.

Berdasarkan permasalahan di atas, maka rumasan masalah dalam penelitian ini yaitu: pertama, bagaimana respon mahasiswa terhadap pembelajaran daring mata kuliah Ulumul Hadits dengan media whatsapp? kedua, bagaimana dampak hasil pembelajaran daring menggunakan whatsapp terhadap prestasi belajar? Sedangkan tujuan dari penelitian ini yakni untuk mengetahui respon mahasiswa terhadap pembelajaran daring mata kuliah Ulumul Hadits dan untuk mengetahui dampak dari hasil pembelajaran daring terhadap prestasi belajar. Adapun manfaat dari penelitian ini adalah; dengan mengetahui respon mahasiswa dan dampak dari hasil pembelajaran daring, dosen pengampu mata kuliah ulumul hadits bisa lebih memperbaharui serta meningkatkan penggunaan media whatsapp dan atau diiringi media daring yang lain secara maksimal serta kesiapan materi dan strategi hingga metode pembelajarannya.

Penelitian terdahulu telah dilakukan oleh Rusdiana, yakni yang berjudul "Respon pada Pembelajaran Daring bagi Mahasiswa Mata Kuliah Pengantar Hukum Indonesia", yang mana ditemukan hasil bahwa pengembangan perkuliahan dengan daring pada mata kuliah pengantar hukum Indonesia dengan menggunakan bahan ajar yang praktis dan mudah dipahami oleh mahasiswa S1 Hukum melalui beberapa tahap, mulai dari pemetaan, pelaksanaan, pembuatan media daring dan evaluasi yang dilakukan melalui tugas. Persamaan dari penelitian tersebut adalah sama-sama melihat respon mahasiswa setelah mengikuti pembelajaran daring. Perbedaan dari penelitian sebelumnya adalah mengenai kesiapan perguruan tinggi terhadap tantangan digital serta jenis mata kuliah yang berbeda.

Studi atas kajian yang dilakukan oleh Sri Widayati yang berjudul "Respon Mahasiswa pada Proses Pembelajaran Mata Kuliah Daring, dalam penelitian tersebut mengkhususkan pada mata kuliah penulisan naskah AUD (Anak Usia Dini)". Penelitian tersebut bertujuan mengetahui respon mahasiswa terkait pembelajaran daring, baik dari efektif maupun efisiensi, tanggung jawab mahasiswa dalam melakukan tugas pembelajaran daring.

Penelitian lain yang dilakukan oleh Nur'aini dengan judul "Pemanfaatan Aplikasi Whatsapp Selama Pandemi Covid-19 Sebagai Sarana Diskusi Pada Mahasiswa Pendidikan Matematik." Persamaan dengan penelitian sebelumnya yaitu sama-sama memanfaatkan media whatsapp dalam pembelajaran daring, yang menjadi perbedaan yaitu mata kuliah yang disampaikan dalam proses pembelajaran daring dalam hal ini adalah ulumul hadits.

Belajar menurut Morris L. Bigger seperti yang dikutip Max Darsono dkk. Dalam bukunya Ismail SM. Adalah perubahan yang menetap dalam diri seseorang yang tidak dapat diwariskan secara genetis. Selajutnya Morris menyatakan bahwa perubahan itu terjadi pada pemahaman (insight), perilaku, persepsi, motivasi, atau campuran dari semuanya secara sistematis sebagai akibat pengalaman dalam situasi-situasi tertentu. Selain pengertian tersebut, sebagai indikator belajar yaitu: a) Belajar ditandai dengan adanya perubahan pengetahuan, sikap, tingkah laku dan keterampilan yang relative tetap dalam diri seseorang sesuai tujuan yang 
diharapkan; b) Belajar terjadi melalui latihan dan pengalaman yang bersifat komulatif; c) Belajar merupakan proses aktif konstruktif yang terjadi melalui mental proses. Mental proses adalah serangkaian proses kognitif yang meliputi persepsi, perhatian, mengingat, berpikir, memecahkan masalah dan lain-lain. (Ismail, 2008, p.9)

Adapun pembelajaran, sebagaimana yang didefinisikan oleh Hamalik ialah suatu kombinasi yang tersusun meliputi unsur-unsur manusiawi, internal material fasilitas perlengkapan dan prosedur yang saling mempengaruhi untuk mencapai tujuan pembelajran. (Hamalik, 2004, p.57)

Sedangkan pembelajaran pada hakikatnya ialah interaksi antara peserta didik dengan lingkungannya sehingga terjadi perubahan perilaku kearah yang lebih baik. Dalam pembelajaran tersebut banyak sekali Faktor yang mempengaruhinya, baik faktor internal yang datang dari individu, maupun faktor eksternal yang dating dari lingkungan individu tersebut. (Mulyasa, 2004, p.100)

Pembelajaran dapat dilakukan secara tatap muka (offline) dan secara jarak jauh menggunakan media internet atau online. Pembelajaran secara langsung dengan tatap muka memberikan kemudahan karena pendidik dapat secara langsung berinteraksi dengan peserta didik. Umpan balik dalam pembelajaran akan tercapai secara langsung di setiap pertemuan. Evaluasi juga langsung dapat dilakukan baik dengan tes tulis, presentasi, maupun praktik secara mandiri dan berkelompok.

Pembelajaran daring perlu direncanakan dengan baik untuk mencapai tujuan pembelajaran. Pemilihan media juga mempengaruhi keefektifan pembelajaran tersebut. Gabungan antara berbagai media diperlukan agar pembelajaran daring dapat berjalan dengan baik. Pembelajaran daring juga harus sesuai dengan materi yang akan disampikan. Pembelajaran daring mempunyai jangkauan yang luas dan fleksibilitas yang tinggi. Ketepatan waktu bisa terjaga dalam pemberian tugas atau evaluasi pembelajaran dengan sistem ontime atau tepat waktu.

Pembelajaran daring juga dapat dilakukan dengan media sosial seperti facebook, whatshap, telegram dan sebagainya. Media sosial tersebut dapat dikelola menjadi media pembelajaran. Setiap peserta didik pasti mempunyai media sosial sesuai dengan kemajuan teknologi di masa kini.

Media ialah suatu alat yang dipakai sebagai saluran (channel) untuk menyampaikan suatu pesan (message) atau informasi dari suatu sumber (resource) kepada penerimanya (receiver). (Soeparno, 1988, p.1). Media pembelajaran adalah semua yang dapat digunakan untuk mengirimkan pesan dari pendidik ke peserta didik. Media pembelajaran daring harus dapat diakses melalui jaringan internet dengan computer atau smartphone. Media yang baik harus mampu membuat pembelajaran lebih menyenangkan dan dapat menjangkau seluruh peserta didik. Pemilihan media sangat penting karena mempengaruhi keberhasilan dalam pembelajaran. Tujuan pembelajaran akan tercapai dengan bantuan media yang efektif.

Media pembelajaran harus mengikuti perkembangan teknologi, sehingga harus dikembangkan secara terus menerus. Peserta didik merespon baik media pembelajaran daring yang menarik. Suasana pembelajaran daring harus dibuat hidup misalnya dengan kuis interaktif. Tema dan gambar yang digunakan harus sesuai materi dan menarik sehingga akan membuat peserta didik tidak bosan dan lebih termotivasi. 
Terdapat kelebihan dan kekurangan dari pembelajaran daring. Salah satu kelebihan dari pembelajaran daring adalah materi dan pembelajaran dapat dikases kapanpun dan dimanapun dengan syarat terdapat koneksi internet yang baik. Juga tergantung dari kreatifitas pendidik dalam mengelola pembelajaran. Kelemahan dari pembelajaran daring adalah sangat bergantung pada ketersediaan paket pulsa dan koneksi internet. Penilaian terhadap mahasiswa juga tidak bisa langsung diawasi dengan baik, dapat dimungkinkan terjadi kecurangan oleh peserta didik atau mahasiswa yang kurang baik.

Menurut Slameto, yang dikutip oleh Saputro bahwa, Faktor yang mempengaruhi proses dan hasil belajar tergolong menjadi 2, yakni; faktor internal dan faktor eksternal. Faktor internal adalah faktor yang berasal dari dalam meliputi faktor jasmaniah (faktor kesehatan, cacat tubuh), Faktor psikologis (intelegensi, perhatian, minat, bakat, motif, kematangan, kesiapan) serta Faktor kelelahan. Sedangkan Faktor eksternal yaitu Faktor yang berasal dari luar, meliputi Faktor keluarga (tingkat pendidikan orangtua, hubungan antar anggota keluarga, penyediaan fasilitas belajar, keadaan ekonomi), Faktor sekolah/kampus, dan Faktor masyarakat. (Saputro, 2020, p.234)

\section{METODE PENELITIAN}

Berisi jenis penelitian, waktu dan tempat penelitian, target/sasaran, subjek penelitian, prosedur, instrumen dan teknik analisis data serta hal-hal lain yang berkait dengan cara penelitiannya. target/sasaran, subjek penelitian, prosedur, data dan instrumen, dan teknik pengumpulan data, serta teknik analisis data serta halhal lain yang berkait dengan cara penelitiannya.

Penelitian ini merupakan jenis penelitian deskriptif kualitatif, yakni mengekplorasi dan memotret suatu situasi social secara menyeluruh, luas dan mendalam. Penelitian berbentuk deskriptif pada umumnya hanya memaparkan saja gambaran yang terjadi pada fenomena, yang dalam hal ini kegiatan yang diteliti kemudian diambil kesimpulan. (Arikunto, 2013, p.36). Penelitian kualitatif adalah penelitian yang dimaksudkan untuk memahami fenomena tentang yang dialami oleh subyek penelitian, misalnya perilaku, persepsi, motivasi, tindakan dan lain-lain, secara holistic dan dengan cara deskripsi dalam bentuk kata-kata dan bahasa, pada suatu konteks khusus yang alamiah dan dengan memanfaatkan berbagai metode ilmiah. (Moelong, 2017, p.6).

Penelitian ini dilakukan pada awal bulan Mei hingga akhir Juni 2021, sedangkan tempat penelitiannya di Sekolah Tinggi Ilmu Tarbiyah Al Marhalah Al 'Ulya Bekasi, pada prodi Pendidikan Agama Islam (PAI). Adapun subyek penelitian dalam hal ini yaitu mahasiswa semester 4 prodi PAI, keseluruhan ada 61 mahasiswa dibagi dua kelas yang mengikuti perkuliahan ulumul hadits, yakni kelas pagi berjumlah 40, dan kelas sore berjumlah 21 mahasiswa.

Dalam proses penelitian ini menggunakan teknik pengumpulan data sebagai berikut; Pertama, observasi partisipatif, sebagaimana yang dinyatakan Susan Stainback dan dikutip oleh Sugiyono bahwa dalam observasi partisipatif, peneliti mengamati apa yang dikerjakan orang, mendengarkan apa yang mereka ucapkan, dan berpartisipasi dalam aktifitas mereka. (Sugiyono, 2015, p.227)

Dengan metode ini peneliti mengamati beberapa perilaku, sikap mahasiswa yang terlibat dalam proses pembelajaran/perkuliahan Ulumul Hadits yang ada di prodi PAI, kelas pagi maupun kelas sore, yang dilakukan secara 
daring/online. Baik dari segi tanggung jawab; keaktifan mahasiswa tersebut maupun kreatifitas serta kedisiplinan mereka dalam mengikuti proses perkuliahan. Kedua, metode wawancara, yakni pertemuan dua orang untuk bertukar informasi dan ide melalui tanya jawab, sehingga dapat dikonstruksikan makna dalam suatu topic tertentu. Dalam hal ini, karena proses pembelajaran dilakukan secara daring, maka peneliti dalam melakukan wawancara dengan mahasiswa juga secara online melalui video call media whatsapp, peneliti mewawancarai tiga mahasiswa; satu mahasiswi tergolong cerdas, satu mahasiswi lagi kemampuan akademikmya tergolong sedang namun rajin dan semangat serta satu mahasiswa yang tergolong kemampuan akademik di bawah rata-rata. Ketiga, metode kuesioner (angket), yakni pengumpulan data yang dilakukan dengan cara memberi seperangkat pertanyaan atau pernyataan tertulis kepada responden untuk dijawabnya. Dengan metode ini peneliti menyusun angket dalam google form, yang berisi pernyataan berkaitan respon mahasiswa dalam penggunaan media whatsapp dalam proses pembelajaran daring, kemudian mengirim linknya via WAG untuk diisi mahasiswa yang mengikuti perkuliahan ulumul hadits. Jumlah pernyataan ada 15, dengan pilihan jawaban; Sangat setuju, Setuju, Ragu, Tidak Setuju dan Sangat tidak setuju. Indikator Respons Mahasiswa yaitu; 1) mendapat kemudahan dalam menggunakan WA, 2) mendapat pemahaman materi dengan menggunakan WA.

Tabel 1. Angket Respon Mahasiswa

\begin{tabular}{|c|c|c|c|c|c|c|c|}
\hline \multirow[t]{2}{*}{ No } & \multirow[t]{2}{*}{ Indikator } & \multirow[t]{2}{*}{ Pernyataan } & \multicolumn{5}{|c|}{ Jawaban } \\
\hline & & & SS & $\mathrm{S}$ & $\mathrm{R}$ & $\mathrm{TS}$ & STS \\
\hline 1 & 2 & $\begin{array}{l}\text { Saya lebih dapat memahami } \\
\text { diskusi kelompok melalui } \\
\text { Whatsapp dibandingkan } \\
\text { diskusi melalui aplikasi lain }\end{array}$ & & & & & \\
\hline 2 & 2 & Belajar Ulumul Hadits dengan & & & & & \\
\hline & & $\begin{array}{l}\text { Whatsapp membuat saya } \\
\text { lebih paham }\end{array}$ & & & & & \\
\hline 3 & 1 & $\begin{array}{l}\text { Saya dapat mengkases } \\
\text { Whatsapp dengan mudah dan } \\
\text { memahami cara menggunakan } \\
\text { aplikasi }\end{array}$ & & & & & \\
\hline 4 & 1 & $\begin{array}{l}\text { Tampilan Whatsapp sangat } \\
\text { mudah dipahami }\end{array}$ & & & & & \\
\hline 5 & 1 & $\begin{array}{l}\text { Di masa wabah covid, aplikasi } \\
\text { whatsapp sangat membantu }\end{array}$ & & & & & \\
\hline 6 & 2 & $\begin{array}{l}\text { Dengan aplikasi whatsapp, } \\
\text { memperoleh informasi, materi } \\
\text { maupun pengumpulan tugas } \\
\text { menjadi lebih mudah dan } \\
\text { fleksibel }\end{array}$ & & & & & \\
\hline 7 & 1 & $\begin{array}{l}\text { Pembelajaran dengan aplikasi } \\
\text { whatsapp lebih mudah } \\
\text { dibandingkan dengan aplikasi } \\
\text { lain }\end{array}$ & & & & & \\
\hline
\end{tabular}




\begin{tabular}{|c|c|c|c|c|c|c|c|}
\hline \multirow[t]{2}{*}{ No } & \multirow[t]{2}{*}{ Indikator } & \multirow[t]{2}{*}{ Pernyataan } & \multicolumn{5}{|c|}{ Jawaban } \\
\hline & & & SS & $\mathrm{S}$ & $\mathrm{R}$ & $\mathrm{TS}$ & STS \\
\hline 8 & 1 & $\begin{array}{l}\text { Dengan whatsapp saya dapat } \\
\text { menyimpan dokumen dengan } \\
\text { mudah }\end{array}$ & & & & & \\
\hline 9 & 2 & $\begin{array}{l}\text { Dengan whatsapp } \\
\text { memungkinkan mahasiswa } \\
\text { umpan balik dengan cepat }\end{array}$ & & & & & \\
\hline 10 & 1 & $\begin{array}{l}\text { Menggunakan aplikasi } \\
\text { whatsapp menghemat quota } \\
\text { dibandingkan aplikasi zoom } \\
\text { atau tatap muka }\end{array}$ & & & & & \\
\hline 11 & 2 & $\begin{array}{l}\text { Dengan menggunakan } \\
\text { whatsapp memungkinkan saya } \\
\text { menyelesaikan tugas dengan } \\
\text { cepat }\end{array}$ & & & & & \\
\hline 12 & 2 & $\begin{array}{l}\text { Dosen aktif memberikan } \\
\text { tanggapan, diskusi dan } \\
\text { pengumuman pada aplikasi } \\
\text { whatsapp. }\end{array}$ & & & & & \\
\hline 13 & 1 & $\begin{array}{l}\text { Menggunakan whatsapp dapat } \\
\text { menghemat biaya dan waktu }\end{array}$ & & & & & \\
\hline 14 & 2 & $\begin{array}{l}\text { Menggunakan whatsapp dapat } \\
\text { melihat langsung penilaian } \\
\text { dan pengumuman dosen }\end{array}$ & & & & & \\
\hline 15 & 2 & $\begin{array}{l}\text { Menggunakan whatsapp } \\
\text { mahasiswa dapat belajar di } \\
\text { mana saja. }\end{array}$ & & & & & \\
\hline
\end{tabular}

Tabel 2. Rentang Skor

\begin{tabular}{|ccc|}
\hline No & Rentang Skor $(\boldsymbol{\%})$ & Kategori \\
\hline 1 & $84-100$ & Sangat Setuju \\
2 & $68-84$ & Setuju \\
3 & $52-68$ & Ragu \\
4 & $36-52$ & Tidak Setuju \\
5 & $20-36$ & Sangat Tidak Setuju \\
\hline
\end{tabular}

Tabel 3. Kelas Penggunaan Aplikasi Whatsapp

\begin{tabular}{|llll|}
\hline No & \multicolumn{1}{c}{$\begin{array}{c}\text { Mahasiswa Ulumul Hadits } \\
\text { Klas Pagi }\end{array}$} & No & $\begin{array}{c}\text { Mahasiswa Ulumul Hadits } \\
\text { Kelas Sore }\end{array}$ \\
\hline 1 & Afif Rafiuddin & 1 & Ahmad Syarifuddin \\
2 & Afifah Mukhlis & 2 & Alvina Adhawiyah \\
3 & Ahmad Fajri & 3 & Amhar Mahmudi
\end{tabular}




\begin{tabular}{|c|c|c|c|}
\hline No & $\begin{array}{c}\text { Mahasiswa Ulumul Hadits } \\
\text { Klas Pagi }\end{array}$ & No & $\begin{array}{c}\text { Mahasiswa Ulumul Hadits } \\
\text { Kelas Sore }\end{array}$ \\
\hline 4 & Ahmad Taufik & 4 & Dewi Zahira \\
\hline 5 & Akhdan Ahmad Alfarizi & 5 & Dia Fitroh Abdul Malik \\
\hline 6 & Alfina Damayanti & 6 & Difta Fahriza \\
\hline 7 & Amelia Chasanah & 7 & Eva Waridah \\
\hline 8 & Anggi Rinata & 8 & Intan Nurhasanah \\
\hline 9 & Dendi Maulana Akbar & 9 & Khoerunnisa \\
\hline 10 & Dias Adika Pratama & 10 & Maulana Akbar \\
\hline 11 & Fadhilah Febriyanti & 11 & Muhammad Arif Rahman \\
\hline 12 & Hilma Nahdiya & 12 & Muhammad Fauzi \\
\hline 13 & Hubbi Mukaffa & 13 & Muhammad Nur Andrian \\
\hline 14 & Irna Melinda & 14 & Ryan Muhammad Sidiq \\
\hline 15 & Khofifah Dianingsih & 15 & Salsabil Zulfa \\
\hline 16 & Maulana Zainul Mafaqih & 16 & Sidqi Abdul Hamid \\
\hline 17 & Mila Liana & 17 & Sultan Rafly Zidan \\
\hline 18 & Millah Najiah & 18 & Sutan Zikri Rauf \\
\hline 19 & M. Afrizal Nurmansyah & 19 & Syifa Fauziyah \\
\hline 20 & M.Arsyil Sayyid & 20 & Udi Tarmidi \\
\hline 21 & M. Dzaky Hawari & 21 & Unggul Ramadhan Subehi \\
\hline 22 & Muhammad Furqon & & \\
\hline 23 & M. Wildan Alfarizy & & \\
\hline 24 & Nurlela Rahmawati & & \\
\hline 25 & Rahmawati Putri Rahayu & & \\
\hline 26 & Ravi Irawan Maulana & & \\
\hline 27 & Ridha Rohadatul Aisy & & \\
\hline 28 & Risma Nur Fajriyah & & \\
\hline 29 & Rizqiyah Shufufah & & \\
\hline 30 & Sabila Azzahra Ramadhani & & \\
\hline 31 & Safitri Dewi & & \\
\hline 32 & Saniyyah Rahmah & & \\
\hline 33 & Siti Fatmawati & & \\
\hline 34 & Siti Marwiyah & & \\
\hline
\end{tabular}




\begin{tabular}{|lll|}
\hline No & \multicolumn{1}{c|}{$\begin{array}{c}\text { Mahasiswa Ulumul Hadits } \\
\text { Klas Pagi }\end{array}$} & $\begin{array}{c}\text { No } \\
\text { Mahasiswa Ulumul Hadits } \\
\text { Kelas Sore }\end{array}$ \\
\hline 35 & Siti Melawati & \\
36 & Siti Nur Azizah & \\
37 & Siti Raidah \\
38 & Zulfiah Farhana \\
39 & Fahrurrozy \\
40 & Mardiansyah \\
\hline
\end{tabular}

Triangulasi sumber dan teknik digunakan untuk mengecek keabsahan data. Data selanjutnya dianalisis menggunakan tiga langkah sebagaimana dinyatakan oleh Miles et al., yakni melalui reduksi data (data reduction), penyajian data (data display), dan penarikan kesimpulan (conclusion drawing/verification). Dalam menganalisis data dari angket, peneliti menggunakan deskriptif kualitatif. Yakni dengan menghitung skor perolehan tiap indikator, kemudian peneliti menganalisis dan menarik kesimpulan. Peneliti ini dapat dicapai dengan membandingkan data hasil penelitian dan data hasil wawancara sebagian mahasiswa.

\section{HASIL DAN PEMBAHASAN}

Dalam pelaksanaan pembelajaran online, untuk mahasiswa semester 4 prodi PAI terdapat 2 kelas yang mengikuti perkuliahan ulumul hadits, yakni kelas pagi berjumlah 40 dan kelas sore berjumlah 21. Data yang diambil dari respon mahasiswa adalah, dari total jumlah 61 mahasiswa kelas pagi dan kelas sore perkuliahan ulumul hadits, yang memberikan respon angket berjumlah 31 mahasiswa.

Penggunaan whatsapp cukup efektif dalam pelaksanaan pembelajaran daring tentunya dengan pendekatan kontekstual. Sebelum proses perkuliahan berlangsung, dosen pengampu atau pembimbing melaksanakan beberapa tahapan yaitu mulai membuat link whatsapp group kuliah, menyiapkan materi ajar lalu mengunggah atau mengeshare materi di whatsapp group mata kuliah. Materi yang diberikan dalam kuliah tersebut yaitu Ulumul Hadits, materi diberikan dalam bentuk pdf. dan terkadang powerpoint serta tambahan materi sekedarnya melalui ketikan langsung di kolom chat WAG serta voice note. Untuk pengumpulan atau pengiriman tugas mahasiswa melalui email perwakilan kelompok ataupun alamat email setiap mahasiswa.

Berdasarkan hasil analisis data di atas, menunjukkan bahwa rata-rata respon mahasiswa terhadap penggunaan whatsapp dalam pembelajaran daring mata kuliah ulumul hadits, sebagai berikut: kelas pagi; indikator pertama tentang respon mahasiswa terhadap kemudahan dalam penggunaan whatsapp, sebanyak 16 orang yang menyatakan sangat setuju, 14 orang yang menyatakan setuju, 8 orang yang menyatakan ragu serta 3 orang yang menyatakan tidak setuju, 0 orang yang menyatakan sangat tidak setuju. Sedangkan kelas sore; respon mahasiswa terhadap kemudahan penggunaan whatsapp terdapat 9 orang yang menyatakan sangat setuju, 6 orang yang menyatakan setuju, 4 orang yang menyatakan ragu, 
dan 2 orang yang menyatakan tidak setuju serta tidak ada yang menyatakan sangat tidak setuju.

Adapun indikator kedua respon mahasiswa kelas pagi mengenai pemahaman materi dengan menggunakan whatsapp; terdapat 9 orang yang menyatakan sangat setuju, 12 orang yang menyatakan setuju, 11 orang yang menyatakan ragu, 6 orang yang menyatakan tidak setuju serta 2 orang yang menyatakan sangat tidak setuju. Sedangkan kelas sore, yang menyatakan sangat setuju ada 6 orang, yang menyatakan setuju ada 7 orang, yang menyatakan ragu ada 4 orang, yang menyatakan tidak setuju ada 3 orang, dan yang menyatakan sangat tidak setuju ada 1 orang.

Ini artinya rata-rata tingkat respon mahasiswa terhadap penggunaan whatsapp berada pada kategori tinggi dan setuju. Hal ini mahasiswa merasakan bahwa manfaat media whatsapp memberikan kemudahan pada mereka baik dalam mengunggah-mengeshare tugas makalah dan tidak terlalu membebani dalam hal paket kuota internet.

Berdasarkan hasil wawancara kepada 3 mahasiswa, diketahui bahwa mahasiswi pertama (berinisial : RS) yang tergolong aktif dan mempunyai kemampuan intelektual tinggi, menyatakan senang dan setuju menggunakan media whatsapp dalam perkuliahan daring, karena praktis dan dapat diakses di mana saja, dan kapan-pun, bisa diiringi dengan aktifitas lain serta tanpa menyedot banyak kuota (paket internet). Sedangkan hasil wawancara dengan mahasiswi satunya (berinisial: SZ) yang tergolong mempunyai kemampuan intelektual sedang namun rajin dan disiplin, menyatakan bahwa dirinya senang sekali dan sangat setuju menggunakan aplikasi whatsapp dalam pembelajaran daring, karena selain menghemat biaya dan tenaga juga dokumen-dokumen tugas serta materi selalu tersimpan dalam kolom chat whatsapp group, sehingga suatu saat dan kapan-pun membutuhkan bisa langsung dibuka dan dibaca. Selain itu dengan adanya diskusi melalui kolom chat WAG, mahasiswa yang biasanya kurang aktif atau malu berkomentar apapun ketika tatap muka dan zoom, dengan WAG tersebut mahasiswa bisa berusaha untuk aktif memberikan komentar, bertanya maupun memberikan tambahan materi serta menjawab beberapa permasalahan. Adapun hasil wawancara bersama mahasiswa satu lagi (berinisial NA) yang tergolong mempunyai kemampuan akademik di bawah rata-rata, menyatakan bahwa; kurang begitu setuju dan kadang ragu menggunakan whatsapp dalam pembelajaran daring. Menurutnya walaupun whatsapp bisa diakses dengan mudah/digunakan kapan saja dan di mana saja, bisa dengan menyambi aktifitas atau pekerjaan lain, namun tetap saja kurang bisa focus mengikuti perkuliahan, sehingga kurang maksimal dalam menyerap-menerima info serta materi dari dosen pembimbing, ada tugas dari dosen pembimbing tidak dikerjakan, karena lupa atau memang focus dengan aktifitas/pekerjaan yang lain.

Selanjutnya analisis perbandingan angket respon mahasiswa dengan hasil wawancara sebagian mahasiswa, ada kesamaan antara keduanya, rata-rata respon mahasiswa memberikan respon positif (setuju) serta mahasiswi yang diwawancarai juga sangat menyetujui terhadap penggunaan aplikasi/media whatsapp dalam proses pembelajaran/perkuliahan daring.

Data variable kedua yakni hasil belajar/ prestasi akademik, diambilkan dari nilai akhir mahasiswa di semester genap 2020-2021. untuk mata kuliah ulumul hadits, maka hasil analisis mengenai variabel kedua, yakni dampak penggunaan aplikasi whatsapp dalam pembelajaran daring terhadap hasil ujian 
akhir semester mata kuliah ulumul hadits, yaitu; kelas pagi, mahasiswa yang mendapatkan nilai 81 hingga 90 (nilia huruf $=$ A) berjumlah 19 orang, yang mendapatkan nilai 66 hingga 80 (nilai huruf $=\mathrm{B}$ ) berjumlah 18 orang serta yang mendapatkan nilai 45 (nilai huruf $=\mathrm{E}$ ) hanya berjumlah 3 orang. Sedangkan nilai akhir perkuliahan ulumul hadits kelas sore, mahasiswa yang mendapatkan nilai 81 hingga 90 (nilai huruf $=$ A) berjumlah 12 orang, dan yang mendapatkan nilai 66 hingga 80 (nilai huruf $=\mathrm{B}$ ) berjumlah 6 , serta yang mendapatkan nilai 51 hingga 65 (nilai huruf $=$ C) berjumlah 3 orang, serta nilai 45 kosong. Dari hasil analisis tersebut, bahwa kelas pagi jumlah mahasiswa keseluruhan 40 , yang mendapatkan nilai $\mathrm{A}=50 \%$, nilai $\mathrm{B}=47 \%$ dan nilai $\mathrm{E}=$ $3 \%$. Adapun kelas sore dengan jumlah keseluruhan mahasiswa ada 21, yang mendapatkan nilai $\mathrm{A}=60 \%$ dan yang mendapatkan nilai $\mathrm{B}=30 \%$ serta yang mendapatkan nilai $\mathrm{C}=10 \%$.

Hasil tersebut menunjukkan rata-rata mahasiswa kedua kelas tersebut memperoleh nilai yang tinggi. Walaupun ada sebagian kecil mahasiswa yang mendapatkan nilai minim, hasil pengamatan peneliti sebagai pembimbing perkuliahan, karena kurang aktif dan kurang kedisiplinan mahasiswa tersebut. Dengan demikian penggunaan whatsapp dalam pembelajaran daring mempunyai dampak yang positif dan signifikan terhadap nilai akhir mahasiswa untuk mata kuliah Ulumul Hadits.

\section{KESIMPULAN}

Kesimpulan dari hasil penelitian ini yaitu respon mahasiswa selama pembelajaran daring dengan menggunakan aplikasi whatsapp terhadap mata kuliah ulumul hadits mendapatkan skor cukup tinggi, dibuktikan dari indikator pertama tentang kemudahan menggunakan whatsapp mendapatkan respon positif atau banyak yang setuju, dan indikator kedua yakni tentang kemudahan memahami materi dengan menggunakan media whatsapp juga direspon secara positif atau setuju. Selanjutnya kesimpulan mengenai rumusan yang kedua yakni tentang dampak penggunaan whatsapp terhadap hasil nilai akhir mahasiswa, sangat berdampak positif atau bagus, artinya nilai mahasiswa di atas rata-rata, baik kelas pagi maupun kelas sore kebanyakn mendapatkan nilai 80 hingga 90 atau nilai huruf $A$.

Saran untuk dosen lebih ditingkatkan lagi dalam memotivasi mahasiswa agar lebih aktif dan kreatif serta disiplin dalam melaksanakan tanggungjawab memenuhi tugas kuliah, serta dosen perlu melaksanakan perkuliahan dengan bahan ajar dan strategi yang menarik dan mengasyikkan, dalam hal ini pendidik perlu dilatih lebih banyak lagi untuk menguasai media online. Masalah pengurangan biaya, dalam hal media, paket internet dan sebagainya, pihak kampus perlu bekerjasama dengan provider internet, dan bekerjasama dengan pemerintah dalam hal pemberian kuota paket internet.

\section{DAFTAR PUSTAKA}

Arikunto, S. (2013). Prosedur Penelitian Suatu Pendekatan Praktik, Jakarta: PT.Rineka Cipta.

Djamarah, B. S. dan Zain A. (2002). Strategi Belajar Mengajar, cet.II, Jakarta: Rineka Cipta.

Hamalik, O. (2001). Kurikulum dan Pembelajaran, Jakarta: PT. Bumi Aksara. 
Ismail, SM. (2008). Strategi Pembelajaran Agama Islam Berbasis PAIKEM, Semarang: RaSAIL Media Group.

Mulyasa, E. (2004). Kurikulum Berbasis Kompetensi: Konsep, Karakteristik dan Implementasi, Bandung: PT.Remaja Rosda Karya.

Moleong, L. J. (2017). Metodologi Penelitian Kualitatif, Bandung: PT.Remaja Rosdakarya.

Nur'ini dkk. (2020). Pemanfaatan Aplikasi Whatsapp Selama Pandemi Covid-19 Sebagai Sarana Diskusi Pada Mahasiswa Pendidikan Matematik, Jurnal Pendidikan Sains, Sosial, dan Agama, 6(2), 13-18

Saputro, M. dkk. (2015). Faktor-faktor yang Mempengaruhi Prestasi Belajar (Studi Korelasi pada Mahasiswa Pendidikan Matematika IKIP PGRI Pontianak), Jurnal Pendidikan Informatika dan Sains, 4(2), 233-246.

Syah, A dan H. (2020). Dampak Covid 19 Pada Pendidikan di Indonesia, Jurnal Sosial dan Budaya Syari-I

Sugiyono, (2013). Metode Penelitian Kuantitatif, Kualitatif dan $R \& D$, Bandung: ALFABETA.

Widayati, S. (2020). Respon Mahasiswa pada Proses Pembelajaran Mata Kuliah Daring, Child Education Journal, 2(1), 43-52 